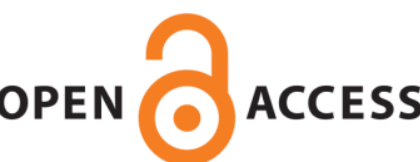

UWS Academic Portal

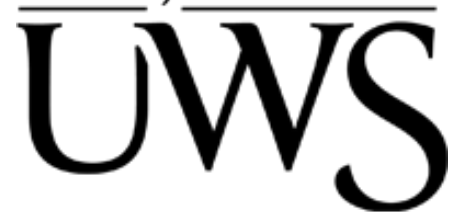

\title{
Energy and carbon emission savings potential of chemical plant by implementing cogeneration technologies
}

Shabbir, Imran; Mirzaeian, M.

Published in:

2016 International Conference for Students on Applied Engineering (ICSAE)

DOI:

10.1109/ICSAE.2016.7810189

Published: 09/01/2017

Document Version

Peer reviewed version

Link to publication on the UWS Academic Portal

Citation for published version (APA):

Shabbir, I., \& Mirzaeian, M. (2017). Energy and carbon emission savings potential of chemical plant by implementing cogeneration technologies. In 2016 International Conference for Students on Applied Engineering (ICSAE) (pp. 207-212). IEEE. https://doi.org/10.1109/ICSAE.2016.7810189

\section{General rights}

Copyright and moral rights for the publications made accessible in the UWS Academic Portal are retained by the authors and/or other copyright owners and it is a condition of accessing publications that users recognise and abide by the legal requirements associated with these rights.

Take down policy

If you believe that this document breaches copyright please contact pure@uws.ac.uk providing details, and we will remove access to the work immediately and investigate your claim. 


\title{
Energy and carbon emission savings potential of chemical plant by implementing cogeneration technologies
}

\author{
Imran Shabbir, Mojtaba Mirzaeian \\ School of Engineering and Computing \\ University of the West of Scotland, Paisley, UK \\ imran.shabbir@uws.ac.uk,mojtaba.mirzaeian@uws.ac.uk
}

\begin{abstract}
In this paper, feasibility analysis to implement different cogeneration systems using agricultural waste (rice husk) along with natural gas as an alternative source of energy for energy saving and cost optimization in a chemical plant is carried out. The authors believe that such feasibility studies by employing rice husk and natural gas in a cycle to improve the energy efficiency and carbon emission savings of chemical plant are limited and therefore this research is timely not only because of the current interest in high-performance cogeneration options but also from the scientific research point of view. The cogeneration technologies implemented are a gas turbine, steam turbine and combined cycle and are evaluated from the energetic and economic point of view to propose a best suitable technology. These technologies are evaluated on the basis of energy utilization factor, simple pay-back period and Annualized life cycle cost (ALCC). The results show that all studied cogeneration options running on thermal match mode have fully satisfied the thermal demand of a chemical plant and in most cases, $70 \%$ electric demand, where combined cycle has the highest energy utilization factor and the least Annualized life cycle cost with the lowest payback period.
\end{abstract}

Keywords-cogeneration; thermoeconomics; chemical plant; energy utilisation factor; annualised life cycle cost

\section{INTRODUCTION}

Chemical plants are energy intensive due to complex processes involved which contribute to the large proportion of industrial carbon emission. The improvement of energy efficiency in these chemical plants is seen as one of the most promising measures for reducing global greenhouse gases emissions $(\mathrm{GHG})$ specifically carbon dioxide $\left(\mathrm{CO}_{2}\right)$ emissions. According to the International Energy Agency (IEA), chemical and petrochemical industry alone accounts for $30 \%$ of industrial energy use and $16 \%$ of global industrial $\mathrm{CO}_{2}$ emissions [1], leading to terrible environmental consequences i.e. pollution, global warming, acid rain etc. $\mathrm{CO}_{2}$ is seen as the main gas responsible for these environmental consequences [2]; thus, this paper focuses specifically on $\mathrm{CO}_{2}$ emissions. Cogeneration or combined heat and power plants (CHP) is a thermodynamically proven efficient energy utilization system that decreases fuel consumption and related GHG emissions by generating two different forms of useful energy (i.e. electrical and thermal energy) from a single fuel input. The system can utilize both fossil fuels and renewable fuels such as biomass as the source of energy. In the chemical industry, electrical energy is used to drive motors, pumps, compressors or fan whereas thermal energy is used for direct process applications or indirectly to make steam, hot water and hot air for the dryer. Steam is a principle energy source for chemical industrial processes and also acts as a solvent to provide both heat and solubility in many industries i.e. pulp and paper industry. The typical method of separate centralized electricity generation and on-site heat generation has a combined efficiency of about 45 percent whereas cogeneration systems can reach efficiency levels of 80 percent [3]. Due to this high overall efficiency of energy use in CHP systems the carbon footprint of separately generated heat and power reduces and hence it is considered as one of the most cost-effective methods of reducing $\mathrm{CO}_{2}$ emissions [4]. Furthermore, the production of electricity being on-site through CHP reduces the burden on utility network and also reduces the transmission and distribution losses.

Feasibility studies of biomass based cogeneration systems in various chemical industries (e.g., sugar, rice, palm oil, paper and wood) as a means of waste disposal and energy recovery have been reported by many researchers. Reference [5] evaluated the techno-economic potential of two biomass (bagasse) based cogeneration systems (steam turbines and gasification combined cycle) for the sugar industry in Mexico to increase energy efficiency. The result of their analysis concluded that the biomass integrated gasification combined cycle system is the most advantageous system to meet all heating requirements and part of the electric requirement with $18 \%$ reduction in total production cost of ethanol. Reference [6] studied the optimal conditions for a combined cycle power generation system using natural gas as a main fuel and syngas from biomass as a supplementary fuel. The results show that about $20 \mathrm{~g} / \mathrm{kWh}$ (gram per kilowatt hours) of $\mathrm{CO}_{2}$ emissions are avoided when using biomass as a supplementary fuel in the supplementary firing chamber as part of the natural gas based combined cycle power plants. Another study by [7] analyzed cogeneration and carbonization as two processing alternatives to reduce environmental and social impacts of conventional rice husk disposal and to improve the overall performance of the rice mill in the Philippines. Integration of a biomass gasification plant into a CHP district heating system fueled 
with natural gas and syngas was evaluated by [8]. The results show that integration of a biomass gasification plant into a district heating system reduces the net emissions of $\mathrm{CO}_{2}$ and is economically profitable. In a recent study by [9], rice husk biomass has been utilized as a sustainable fuel for rural electrification in Myanmar. It has been shown that the rice husk biomass power system is not only the sustainable and affordable option to rural electrification but can be considered as a financially viable business model to provide the grid quality power to the rural population. A technical and economic feasibility study for a natural gas-fueled cogeneration plant was conducted by Fantozzi et al. [10] in an Italian pasta and animal feed factory. In another study, reference [11] applied net present value (NPV), internal rate of return (IRR) and payback period (PBP) to select between two CHP units for a tyre manufacturing chemical plant in Spain. Energy efficiency measures in Swedish pulp and paper mills are investigated by Mollersten et al. [12] to study the potential of $\mathrm{CO}_{2}$ reduction. The results of the study show that the cogeneration of heat and power is the most cost-effective alternatives that also have large $\mathrm{CO}_{2}$ reduction potentials in Swedish pulp and paper mills. Some of other works include, a study on cogeneration in a sugar factory by $[13,14]$, a textile industry by $[15,16]$, pulp and paper mill by $[17,18]$ and palm oil mill by [19]. The review of previous studies supports the fact that utilization of biomass guarantees the heat demand along with full or part of power demands in a chemical plant with a low level of pollution, low ash content and low sulphur concentration in addition to the use of a renewable and cheap source of energy for heat and electricity generations. This shows that there is a strong need to conduct further investigations and also to present simple and accurate approaches for developing biomass-based cogeneration systems.

The aim of this study is to calculate the energy and carbon emission savings potential of a chemical plant by implementing different cogeneration technologies and are evaluated from the energetic and economic point of view to propose a best suitable technology.

\section{CHEMICAL PLANT CHARACTERISTICS}

The chemical plant analyzed in this study produces a paperboard of different weight for bookbinding purposes. The annual average demand of this plant is $3379 \mathrm{~kW}$ of electricity and $40,358 \mathrm{~kW}$ of thermal energy which is in the form of saturated steam at 14.7 bars of $197^{\circ} \mathrm{C}$ and flow rate of 12.9 $\mathrm{kg} / \mathrm{s}$ consumes at Unit 1 (pulping) and Unit 2 (paper machine) respectively. At the current situation, six installed fire and water tube boilers are used to meet the thermal energy requirement of the plant and electricity is purchased from the utility. The motivation of this study is the poor thermal efficiency $(53 \%)$ of existing boilers used to produce steam and chemical plant reliance on the grid for electricity. To improve the energy efficiency of this chemical plant and reduce its $\mathrm{CO}_{2}$ emission, implementation of different CHP options is studied and the results of the energetic and economic analysis are compared in this study. Fig. 1 indicates the annual thermal and electric demands and proposed electric generation for a chem.

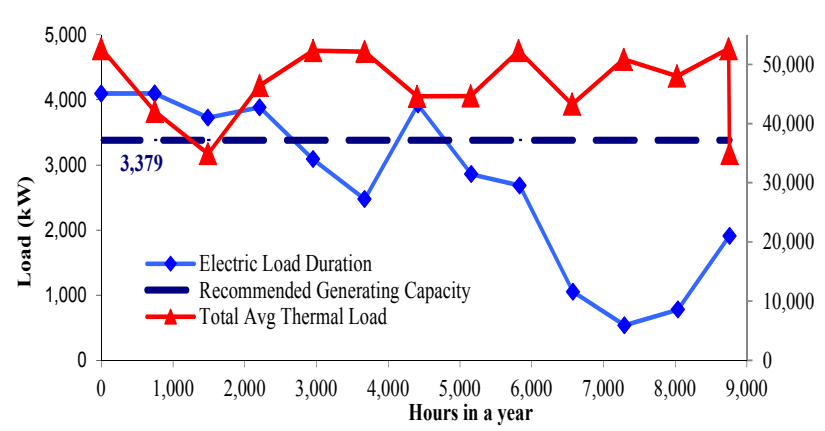

Fig. 1. Energy demand and projected electrical energy generation of a chemical plant

electric demands and proposed electric generation for a chemical plant.

\section{THERMO-ECONOMIC METHODOLOGY}

Three proposed cogeneration technologies presented in this study are a gas turbine, steam turbine and combined cycle and contains three main components including a prime mover (gas or steam turbine); heat exchangers for heat recovery and electric generator. In all cases, the plant is designed to operate with rice husk as biomass fuel for $1931 \mathrm{~h}$ (hours) and then with natural gas for $4779 \mathrm{~h}$ in a continuous cycle based on same consumption of fuel as currently fed to the chemical plant. The fixed parameters used for the evaluation and comparison of three CHP configurations are given in Table 1.

The main assumptions made are as follows; system operates in steady state; ideal gas principles are applied to air and gases, all combustion reactions are complete and the air is feed at standard design conditions $\left(15^{\circ} \mathrm{C}, 1.013\right.$ bars, $60 \%$ relative humidity) in gas turbine and gasifier. A detailed description of each cogeneration system and their process flow diagrams is presented as follows.

TABLE 1. SUMMARY OF FIXED PARAMETERS USED FOR VARIOUS PLANT COMPONENTS

\begin{tabular}{|c|c|c|c|}
\hline Parameter & Value & Parameter & Value \\
\hline$\eta_{\mathrm{b}}$ & 0.80 & $\eta_{\mathrm{p}}$ & 0.80 \\
\hline$\eta_{\text {gen }}$ & 0.97 & $\eta_{\mathrm{gt}}$ & 0.85 \\
\hline$\eta_{\mathrm{st}}$ & 0.85 & $\eta_{\mathrm{c}}$ & 0.82 \\
\hline $\mathrm{T}_{\mathrm{o}}(\mathrm{K})$ & 288 & $\eta_{\mathrm{cc}}$ & 0.98 \\
\hline $\mathrm{P}_{\mathrm{o}}(\mathrm{kPa})$ & 101.32 & $\mathrm{C}_{\mathrm{p}, \mathrm{gas}}(\mathrm{kJ} / \mathrm{kg} \mathrm{K})$ & 1.148 \\
\hline$\Delta \mathrm{T}_{\text {approach }}(\mathrm{K})$ & 8.33 & $\mathrm{C}_{\mathrm{p}, \text { air }}(\mathrm{kJ} / \mathrm{kg} \mathrm{K})$ & 1.004 \\
\hline$\Delta \mathrm{T}_{\text {pinch }}(\mathrm{K})$ & 8.33 & $\mathrm{x}_{\mathrm{out}}$ & 0.95 \\
\hline $\mathrm{CV}_{\mathrm{R} . \mathrm{H}}(\mathrm{kJ} / \mathrm{kg})$ & 15,217 & $\mathrm{CV}$ N.G $(\mathrm{kJ} / \mathrm{kg})$ & 42,873 \\
\hline $\mathrm{i}(\%)$ & 10 & $\mathrm{n}(\mathrm{years})$ & 30 \\
\hline $\mathrm{P}_{\mathrm{e}, \mathrm{p}}(\mathrm{US} \$ / \mathrm{kWh})$ & 0.23 & $\mathrm{P}_{\mathrm{e}, \mathrm{s}}(\mathrm{US} \$ / \mathrm{kWh})$ & 0.115 \\
\hline
\end{tabular}




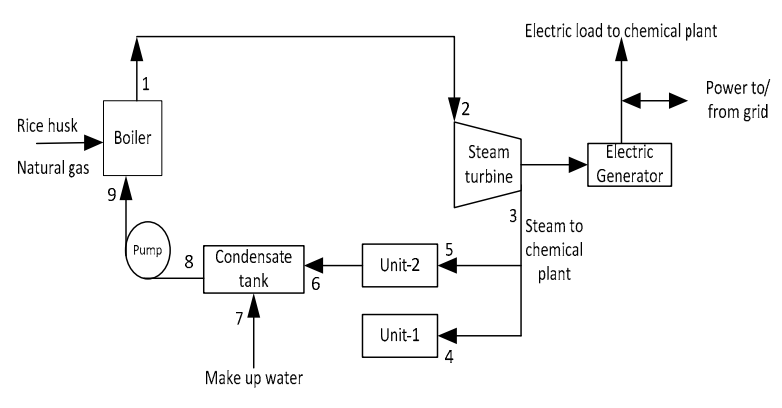

Fig. 2. Flow schematic of the configuration I

\section{A. Configuration I}

The first configuration (case 1) analyzed is based on Rankine cycle and consists of a steam turbine as shown in Fig. 2. In this case, superheated steam generated in the boiler is expanded in a steam turbine to generate electricity and an exhaust of steam turbine is used to meet the process heat demands of the chemical plant.

\section{B. Configuration II}

The air basic power cycle in the second configuration (case 2 ) is based on Brayton cycle as shown in Fig. 3. It begins by adiabatic air compression in the compressor which then mixed with fuel in combustion chamber. The resulting mixture of high-temperature combustion gas from combustion chamber then expanded in a gas turbine to generate electricity. The exhaust of gas turbine is utilized in heat recovery steam generator (HRSG) with the aid of supplementary firing to generate required steam for a chemical plant.

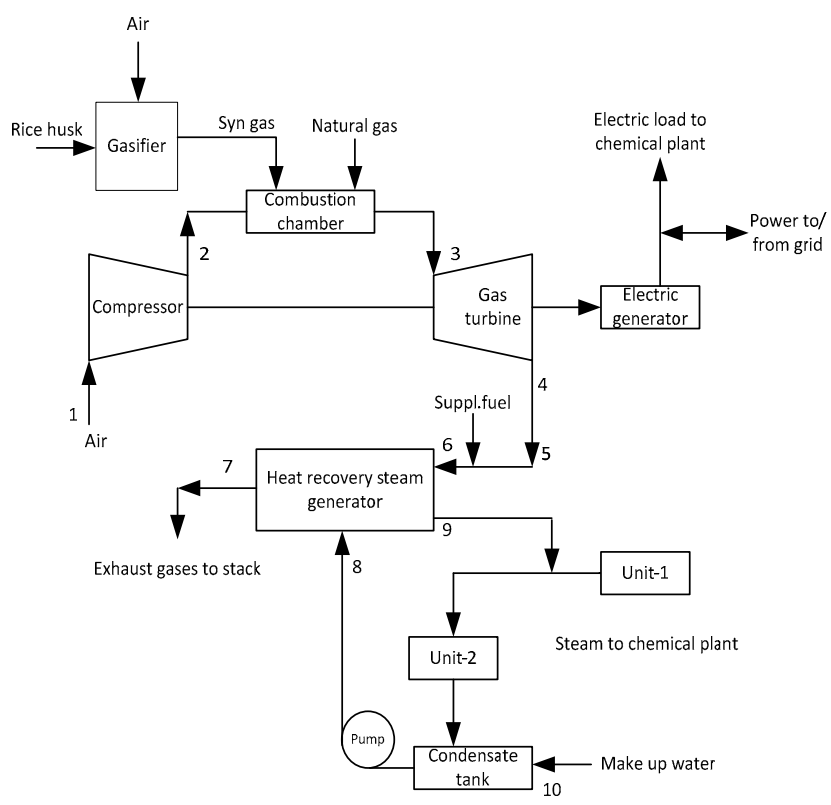

Fig. 3. Flow schematic of the configuration II

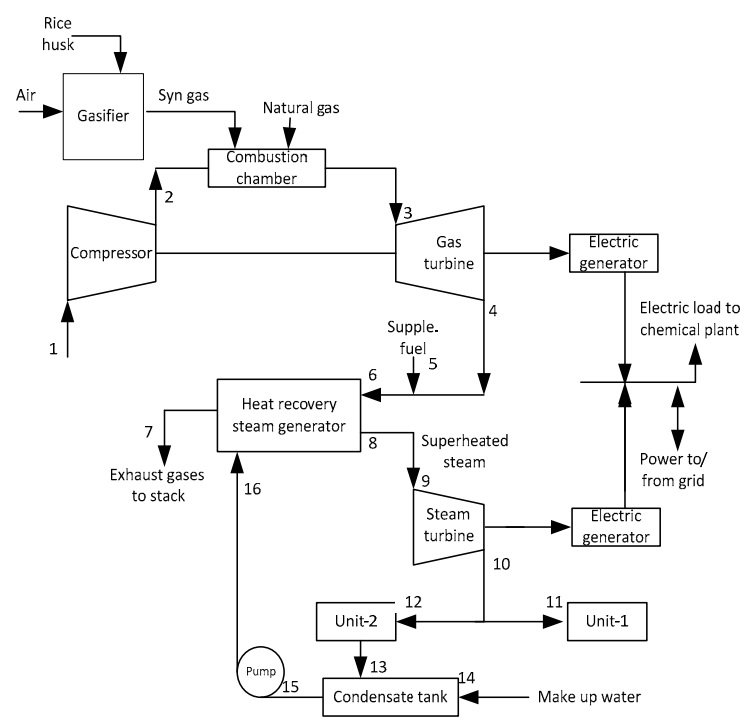

Fig. 4. Flow schematic of the configuration III

\section{Configuration III}

The third configuration (case 3) is based on combined cycle configuration where topping cycle (gas turbine) produces electrical energy and rejects heat is used in HRSG to produce superheated steam for bottoming cycle (steam turbine) to produce electrical energy and to provide process heat for a chemical plant.

The operation strategy proposed in this study is "heat match mode" because of following reasons:

- Thermal energy requirement is almost ten times more than the electric requirement

- Export of power to the grid is not economically viable in current electricity selling prices

- Standby demand charge for electricity is not defined in case of CHP system shut down and electric supply required from power grid in the area of proposed cogeneration

\section{Comparison of cogeneration options}

There are several performance assessment parameters for cogeneration systems comparison in the literature. This study is based on the thermo-economic evaluation of the system which combines thermodynamic concepts with economic considerations. This approach consists of a detailed energy analysis, an economic analysis conducted at the component level, calculation of the cost of each stream using the "thermoeconomic functional analysis" proposed by [20] and used by many other researchers $[17,21,22]$

Energy utilization factor $(E U F)$ is employed to evaluate the energetic analysis of different options and can be expressed as [19]: 


$$
E U F=(P+H) / E
$$

The economic assessment and comparison of the cogeneration options applied in this work are performed based on Annualized Life Cycle Cost (ALCC) analysis calculated by the following equation [23]:

$$
\begin{gathered}
\text { ALCC }=\left(C_{p} * C R F\right)+\text { Annual operating cost- } \\
\text { (Annual savings from selling electricity }+ \text { Avoided } \\
\text { cost of electricity purchase) }
\end{gathered}
$$

Usually the purchase cost of any equipment, $C_{p}$, is obtained from vendors of specific models, however the approximated values at different operating conditions can be calculated from the thermodynamics relationships given in Table 2 where the cost of installation, electrical equipment, control systems, piping are taken into account in the coefficients used in each equation.

Capital Recovery Factor (CRF) converts total purchase cost of equipment into a stream of equal annual payments over a specified time, $n$, at a specified interest rate, $i$, and can be calculated as [22]:

$$
C R F=\frac{i(1+i)^{n}}{(1+i)^{n}-1}
$$

The annual operating cost of a cogeneration system in this study consists of the fuel, labor, and maintenance costs. The price of rice husk and natural gas used are taken as 0.10 and 0.28 (US $\$ / \mathrm{kg}$ ) respectively based on the current actual prices paying by chemical plant [24]. Labor cost is calculated by assuming automated plants running $24 \mathrm{hrs}$ per day for 6710 hours in a year. Maintenance cost of $6 \%$ of the total equipment

TABLE 2. RELATIONSHIPS FOR THE CALCULATION OF THE PURCHASE COST OF MAJOR EQUIPMENT'S

\begin{tabular}{|c|l|}
\hline Parameter & \multicolumn{1}{|c|}{ Equation } \\
\hline Boiler & $C_{P, b l}=740\left(Q_{b l}\right)^{0.8} \exp \left(\frac{P_{1}-2}{14.29}\right) \exp \left(\frac{T_{1}-350}{446}\right)$ \\
\hline Pump & $C_{P, p}=3540\left(W_{P}\right)^{0.71}$ \\
\hline $\begin{array}{c}\text { Air } \\
\text { compressor } \\
\text { Electric } \\
\text { generator }\end{array}$ & $C_{P, a c}=\left(\frac{75 \dot{m}_{\text {air }}}{0.9-\eta_{C}}\right)\left(\frac{P_{2}}{P_{1}}\right) \ln \left(\frac{P_{2}}{P_{1}}\right)$ \\
\hline Gas turbine & $C_{P, g g}=60\left(W_{\text {net }}\right)^{0.95}=\left(\frac{1536 \dot{m}_{\text {gas }}}{0.92-\eta_{g t}}\right) \ln \left(\frac{P_{3}}{P_{4}}\right)\left(1+\exp \left(0.036 T_{3}-54.4\right)\right)$ \\
\hline $\begin{array}{c}\text { Steam } \\
\text { turbine }\end{array}$ & $C_{P, s t}=6000\left(W_{\text {net }}\right)^{0.7}$ \\
\hline $\begin{array}{c}\text { Combustion } \\
\text { chamber }\end{array}$ & $C_{P, c c}=\left(\frac{48.64 \dot{m}_{\text {air }}}{0.995-\frac{P_{3}}{P_{2}}}\right)\left(1+\exp \left(0.018 T_{3}-26.4\right)\right)$ \\
\hline Gasifier & $C_{P, \text { gasifier }}=1600\left(\dot{m}_{\text {ricehusk }}\right)^{0.67}$ \\
\hline HRSG & $C_{P, \text { HRSG }}=3650\left(\left(\frac{Q_{\text {econ }}}{L M T D_{\text {ccon }}}\right)^{0.8}+\left(\frac{Q_{\text {evap }}}{L M T D_{\text {evap }}}\right)^{0.8}\right)+11820 \dot{m}_{s}+658\left(\dot{m}_{\text {gas }}\right)^{1.2}$ \\
\hline
\end{tabular}

cost [21] is considered where natural gas is used and $10 \%$ of the total equipment cost is used where rice husk is used due to gas cleaning requirement in case of gas turbine and ash fouling and slagging in boiler in case of steam turbine [25].

\section{E. $\mathrm{CO}_{2}$ emission reduction potential from proposed $\mathrm{CHP}$ configurations}

The calculation of reduction in $\mathrm{CO}_{2}$ emissions in result of implementation of proposed cogeneration systems is based on the methodology presented by [12] for defining the global $\mathrm{CO}_{2}$ emission reduction:

$$
C \mathrm{O}_{2 \text { reduction }}=\mathrm{CO}_{2 \text { fuel }}+\mathrm{CO}_{2 \text { grid }}
$$

Where $\mathrm{CO}_{2}$ fuel is the change in $\mathrm{CO}_{2}$ emissions due to fuel savings by cogeneration and $\mathrm{CO}_{2}$ grid is the change in $\mathrm{CO}_{2}$ emissions reduction result because of purchasing zero/less grid-based electricity depending upon mill. The average $\mathrm{CO}_{2}$ emission factors used in this study are $0.18407 \mathrm{~kg} \mathrm{CO}_{2} / \mathrm{kWh}$, $0.01731 \mathrm{~kg} \mathrm{CO} / \mathrm{kWh}$ and $0.47337 \mathrm{~kg} \mathrm{CO} / \mathrm{kWh}$ for natural gas, rice husk and purchased electricity from grid respectively [24].

\section{RESULTS AND DISCUSSION}

The energy balance including electrical efficiency and energy utilization factor (EUF) of three different CHP cases analyzed are shown in Table 3 . The steam requirement is kept constant in all the options to satisfy the thermal need of the chemical plant. The energy utilization factor of cogeneration plants is usually in the range of $70-80 \%$ [26]. The results of energy utilization factor for this analysis shows a utilization factor of $75 \%$ for case $3,54 \%$ for case 2 , and $73 \%$ for case 1 indicating that the energy is best used in case 3 (combined cycle configuration). The results of energy balance also show that even the lowest EUF options among the compared cogeneration cases have higher EUF than the existing energy system in a chemical plant; hence thermodynamically cogeneration is suitable for the studied chemical plant.

The results of annual fuel consumption, electricity generation and its export to the grid and avoided electricity of all cogeneration options are summarised in Table 4 . The amount of fuel saving by comparing existing facility with high EUF cogeneration case 3 (combined cycle) is 2,016 tonnes and

TABLE 3. ENERGY BALANCE ABSTRACT OF STUDIED COGENERATION SYSTEMS

\begin{tabular}{|l|c|c|c|c|}
\hline \multicolumn{1}{|c|}{ Description } & $\begin{array}{c}\text { Existing } \\
\text { system }\end{array}$ & $\begin{array}{c}\text { Case } \\
\mathbf{1}\end{array}$ & $\begin{array}{c}\text { Case } \\
\mathbf{2}\end{array}$ & $\begin{array}{c}\text { Case } \\
\mathbf{3}\end{array}$ \\
\hline Energy input (MW) & 61.23 & 49.03 & 51.02 & 53.47 \\
\hline steam requirement (Kg/s) & 12.9 & 12.9 & 12.9 & 12.9 \\
\hline Electricity production (MW) & 0 & 10.88 & 2.43 & 15.05 \\
\hline Process heat recovery (MW) & 25.23 & 25.23 & 25.23 & 25.23 \\
\hline Electrical efficiency (\%) & 0 & 22.75 & 5.07 & 28.28 \\
\hline Energy utilisation factor (\%) & 41.2 & 73.6 & 54.21 & 75.33 \\
\hline
\end{tabular}


TABLE 4. ANNUAL FUEL CONSUMPTION AND ELECTRICAL ENERGY DATA FOR EXISTING SYSTEM AND PROPOSED COGENERATION CASES

\begin{tabular}{|c|c|c|c|c|c|c|c|c|c|}
\hline \multirow{3}{*}{$\begin{array}{l}\text { Parameters } \\
\text { Fuel type }\end{array}$} & \multirow{3}{*}{ Units } & \multirow{2}{*}{\multicolumn{2}{|c|}{ Existing system }} & \multicolumn{6}{|c|}{ Cogeneration Options } \\
\hline & & & & \multicolumn{2}{|c|}{ Case 1} & \multicolumn{2}{|c|}{ Case 2} & \multicolumn{2}{|c|}{ Case 3} \\
\hline & & $\begin{array}{c}\text { Natural } \\
\text { gas }\end{array}$ & $\begin{array}{l}\text { Rice } \\
\text { husk }\end{array}$ & $\begin{array}{c}\text { Natural } \\
\text { gas }\end{array}$ & $\begin{array}{l}\text { Rice } \\
\text { husk }\end{array}$ & $\begin{array}{c}\text { Natural } \\
\text { gas }\end{array}$ & $\begin{array}{l}\text { Rice } \\
\text { husk }\end{array}$ & $\begin{array}{c}\text { Natural } \\
\text { gas }\end{array}$ & $\begin{array}{l}\text { Rice } \\
\text { husk }\end{array}$ \\
\hline Fuel consumption & tonnes & 23,280 & 26,500 & 19,093 & 21,953 & 18,065 & 23,305 & 21,264 & 24,427 \\
\hline Electricity production & $\mathrm{MWh}$ & 0 & 0 & 50,945 & 21,439 & 11,596 & 4,685 & 70,799 & 29,534 \\
\hline Electricity requirement & $\mathrm{MWh}$ & 16,149 & 6,525 & 16,149 & 6,525 & 16,149 & 6,525 & 16,149 & 6,525 \\
\hline Electricity transferred to grid & MWh & 0 & 0 & 34,796 & 14,914 & 0 & 0 & 54,650 & 23,009 \\
\hline Electricity bought from grid & MWh & 16,149 & 6,525 & 0 & 0 & 4,553 & 1,840 & 0 & 0 \\
\hline Avoided electricity purchases & MWh & 0 & 0 & 16,149 & 6,525 & 11,596 & 4,685 & 16,149 & 6,525 \\
\hline
\end{tabular}

TABLE 5. SUMMARY OF THE ANNUAL OPERATING COSTS OF STUDIED COGENERATION OPTIONS

\begin{tabular}{|l|c|c|c|c|c|c|}
\hline \multicolumn{1}{|c|}{ Cost (millions US\$) } & \multicolumn{2}{c|}{ Case 1 } & \multicolumn{2}{c|}{ Case 2 } & \multicolumn{2}{c|}{ Case 3 } \\
\hline Type of fuel & Natural gas & Rice husk & Natural gas & Rice husk & Natural gas & Rice husk \\
\hline Fuel cost & 5.33 & 2.20 & 5.05 & 2.33 & 5.94 & 2.44 \\
\hline Electricity purchase cost & 0 & 0 & 1.03 & 0.42 & 0 & 0 \\
\hline Labor cost & 0.041 & 0.016 & 0.054 & 0.022 & 0.081 & 0.033 \\
\hline Maintenance cost & 0.22 & 0.45 & 0.33 & 0.56 & 0.35 & 0.67 \\
\hline Annual operating cost & 5.59 & 2.66 & 6.46 & 3.33 & 6.37 & 3.14 \\
\hline
\end{tabular}

TABLE 6. COMPARISON OF ALCC OF DIFFERENT COGENERATION OPTIONS

\begin{tabular}{|l|c|c|c|c|c|c|}
\hline \multirow{2}{*}{ Cost (millions US\$) } & \multicolumn{2}{|c|}{ Case 1 } & \multicolumn{2}{c|}{ Case 2 } & \multicolumn{2}{c|}{ Case 3 } \\
\cline { 2 - 8 } & Natural gas & Rice husk & Natural gas & Rice husk & Natural gas & Rice husk \\
\hline Equipment purchase cost & 3.68 & 4.49 & 5.56 & 5.56 & 5.81 & 6.67 \\
\hline Annual operating cost & 5.59 & 2.66 & 6.46 & 3.33 & 6.37 & 3.14 \\
\hline Avoided electricity purchases & 1.24 & 0.97 & 0.78 & 0.59 & 1.09 & 0.82 \\
\hline Financial saving from CHP & 2.61 & 1.12 & 0 & 0 & 4.10 & 1.73 \\
\hline ALCC & 2.19 & 1.11 & 6.34 & 3.40 & 1.87 & 1.39 \\
\hline Overall ALCC & \multicolumn{2}{|c|}{3.30} & & & 3.74 & 3.28 \\
\hline
\end{tabular}

2,073 tonnes of natural gas and rice husk respectively. This fuel saving would directly generate revenue worth 0.56 and 0.21 million US\$ from natural gas and rice husk respectively, resulting in an overall saving of 0.77 million US\$. The results of operating cost analysis of the proposed cogeneration systems based on fuel, labor, purchased electricity and maintenance costs are given in Table 5. These results are used for the calculation of annualized life cycle costs (ALCC) given in Table 6.

The data given in Table 6 shows that from an economic point of view the combined cycle cogeneration system has the lowest overall ALCC among different cogeneration options when using natural gas for 4779 hours and rice husk for 1931 hours in a cycle continuously. This shows that the combined cycle cogeneration system can be considered as the most economically viable option for the studied chemical plant. The comparison of existing energy system with the proposed combined cycle cogeneration will save the avoided electricity purchase cost of 1.91 million US\$ besides providing the revenue worth 5.83 million US\$ per year through power export to the grid resulting in an overall saving of 7.74 million US\$.

\section{CONCLUSION}

Thermoeconomic feasibility of cogeneration system for a chemical plant is analyzed when natural gas and rice husk is used in a cycle as its primary energy source. It is found that the chemical plant has a good potential for combined cycle cogeneration and is viable in both technical and economic perspectives based on energy utilization factor and annualized life cycle cost. The energetic analysis of different options indicated that the combined cycle cogeneration system generates 77,659 MWh of electricity in addition to supplying 
the required process heat and electricity for the chemical plant which results in 7.76 million US\$ annually saving. The results of $\mathrm{CO}_{2}$ emission analysis also show that combined cycle cogeneration option gives the maximum percentage of $\mathrm{CO}_{2}$ emission reduction $48 \%$ compared to the existing system. Base on the economic analysis, it is also concluded that the ALCC of combined cycle cogeneration system is least and hence is the most economically viable option for the chemical plant. It is concluded that the proposed combined cycle can provide an attractive saving in annual operating cost with a simple payback period of 4.1 years.

TABLE 7. Nomenclature

\begin{tabular}{|c|c|c|c|}
\hline Symbols & Description & Symbols & Description \\
\hline$\eta_{b}$ & Boiler efficiency & $\mathrm{n}_{\mathrm{st}}$ & $\begin{array}{l}\text { Steam turbine } \\
\text { efficiency }\end{array}$ \\
\hline$\eta_{\text {gen }}$ & Generator efficiency & $\eta_{\mathrm{gt}}$ & $\begin{array}{c}\text { Gas turbine } \\
\text { efficiency }\end{array}$ \\
\hline$\eta_{c}$ & $\begin{array}{c}\text { Compressor } \\
\text { efficiency }\end{array}$ & $\eta_{\mathrm{cc}}$ & $\begin{array}{c}\text { Combustion } \\
\text { chamber efficiency }\end{array}$ \\
\hline$\eta_{p}$ & Pump efficiency & $P_{o}$ & $\begin{array}{c}\text { Atmospheric } \\
\text { pressure }\end{array}$ \\
\hline$T_{o}$ & $\begin{array}{l}\text { Atmospheric } \\
\text { temperature }\end{array}$ & $i$ & interest rate \\
\hline$P$ & Power output & $n$ & $\begin{array}{c}\text { useful life of the } \\
\text { equipment }\end{array}$ \\
\hline$H$ & $\begin{array}{l}\text { Process heat } \\
\text { requirements }\end{array}$ & $Q$ & $\begin{array}{c}\text { Energy input in } \\
\text { boiler }\end{array}$ \\
\hline$E$ & Energy input & $W$ & Work done \\
\hline$m$ & Mass & $P$ & Pressure \\
\hline$\dot{m}$ & Mass flow rate & $T$ & Temperature \\
\hline$C V$ & Calorific value & LMTD & $\begin{array}{l}\text { Log mean } \\
\text { temperature } \\
\text { difference }\end{array}$ \\
\hline$C_{P}$ & Purchase cost & $P_{e, s}$ & $\begin{array}{l}\text { selling cost of } \\
\text { electricity }\end{array}$ \\
\hline$P_{e, p}$ & $\begin{array}{l}\text { Purchase cost of } \\
\text { electricity }\end{array}$ & & \\
\hline
\end{tabular}

\section{REFERENCES}

[1] International Energy Agency (IEA), “Tracking Industrial Energy Efficiency and CO2 Emissions."

[2] R. N. E. Huaman and T. X. Jun, "Energy related $\mathrm{CO}_{2}$ emissions and the progress on CCS projects: a review," Renew. Sustain. Energy Rev., vol. 31, pp. 368-385, 2014.

[3] Oak Ridge National Laboratory (ORNL), "COMBINED HEAT AND POWER: Effective Energy Solutions for a Sustainable Future,” 2008.

[4] International Energy Agency (IEA), "Combined Heat and PowerEvaluating the Benefits of Greater Global Investment," 2008.

[5] L. E. Rincón, L. A. Becerra, J. Moncada, and C. A. Cardona, "Technoeconomic analysis of the use of fired cogeneration systems based on sugar cane bagasse in south eastern and mid-western regions of Mexico," Waste and biomass valorization, vol. 5, no. 2, pp. 189-198, 2014.

[6] N. V Gnanapragasam, B. V Reddy, and M. A. Rosen, "Optimum conditions for a natural gas combined cycle power generation system based on available oxygen when using biomass as supplementary fuel," Energy, vol. 34, no. 6, pp. 816-826, 2009.

[7] R. L. Burritt, C. Herzig, and B. D. Tadeo, "Environmental management accounting for cleaner production: The case of a Philippine rice mill," J. Clean. Prod., vol. 17, no. 4, pp. 431-439, 2009.
[8] E. Fahlén and E. O. Ahlgren, "Assessment of integration of different biomass gasification alternatives in a district-heating system," Energy, vol. 34, no. 12, pp. 2184-2195, 2009.

[9] R. Pode, G. Pode, and B. Diouf, "Solution to sustainable rural electrification in Myanmar," Renew. Sustain. Energy Rev., vol. 59, pp. 107-118, 2016.

[10] F. Fantozzi, S. D. Ferico, and U. Desideri, "Study of a cogeneration plant for agro-food industry," Appl. Therm. Eng., vol. 20, no. 11, pp. 993-1017, 2000.

[11] M. V Biezma and J. R. San Cristobal, "Investment criteria for the selection of cogeneration plants - a state of the art review," Appl. Therm. Eng., vol. 26, no. 5, pp. 583-588, 2006.

[12] K. Möllersten, J. Yan, and M. Westermark, "Potential and costeffectiveness of CO 2 reductions through energy measures in Swedish pulp and paper mills," Energy, vol. 28, no. 7, pp. 691-710, 2003.

[13] A. P. Mann, "Cogeneration of sugarcane bagasse for renewable energy production," Sugarcane-Based Biofuels Bioprod., pp. 235-258, 2016.

[14] J. Raghu Ram and R. Banerjee, "Energy and cogeneration targeting for a sugar factory," Appl. Therm. Eng., vol. 23, no. 12, pp. 1567-1575, 2003.

[15] O. Tang and B. Mohanty, "Industrial energy efficiency improvement through cogeneration: A case study of the textile industry in Thailand," Energy, vol. 21, no. 12, pp. 1169-1178, 1996.

[16] V. Ramesh and R. Saravannan, "Reliability assessment of cogeneration power plant in textile mill using fault tree analysis," J. Fail. Anal. Prev., vol. 11, no. 1, pp. 56-70, 2011.

[17] I. Shabbir and M. Mirzaeian, "Feasibility analysis of different cogeneration systems for a paper mill to improve its energy efficiency," Int. J. Hydrogen Energy, 2016.

[18] G. Comodi, L. Cioccolanti, L. Pelagalli, M. Renzi, S. Vagni, and F. Caresana, "A survey of cogeneration in the Italian pulp and paper sector,” Appl. Therm. Eng., vol. 54, no. 1, pp. 336-344, 2013.

[19] Z. Husain, Z. A. Zainal, and M. Z. Abdullah, "Analysis of biomassresidue-based cogeneration system in palm oil mills," Biomass and Bioenergy, vol. 24, no. 2, pp. 117-124, 2003.

[20] C. Frangopoulos and M. von Spakovsky, "A Global Environomic Approach for Energy Systems Analysis and Optimization (Part I)," 1993.

[21] A. Lazzaretto and A. Macor, "Direct calculation of average and marginal costs from the productive structure of an energy system," J. energy Resour. Technol., vol. 117, no. 3, pp. 171-178, 1995.

[22] F. C. Knopf, Modeling, analysis and optimization of process and energy systems. John Wiley \& Sons, 2011.

[23] M. A. Mujeebu Jayaraj, S, Ashok, S, Abdullah, MZ, Khalil, M, "Feasibility study of cogeneration in a plywood industry with power export to grid," Appl. Energy, vol. 86, no. 5, pp. 657-662, 2009.

[24] Cleaner production institute (CPI), "Responding to the Environmental Challenge Pakistan's Pulp \& Paper Sector," 2013. [Online]. Available: http://www.cpi.org.pk/CPP_Broucher.aspx.

[25] Z. T. Lian, K. J. Chua, and S. K. Chou, "A thermoeconomic analysis of biomass energy for trigeneration,” Appl. Energy, vol. 87, no. 1, pp. 8495, 2010.

[26] I. Zakaria, "Renewable energy program from national perspective," Renew. Energy Power Progr. Palm Oil Ind., 2002. 